\title{
Подготовка кадров и развитие квалификаций химического, нефтехимического и биотехнологического комплекса
}

\author{
Т.А.Петрова, \\ пресс-секретарь Российского Союза химиков \\ petrova@ruschemunion.ru
}

\begin{abstract}
21 ноября 2019 года состоялось очередное расширенное совместное заседание Комиссии Российского союза промышленников и предпринимателей (РСПП) по химической промышленности и Совета Российского Союза химиков. В качестве основных тем для дискуссии были заявлены проблемы и перспективы развития кадрового потенциала химической отрасли, а также реализация комплексных научно-технических проектов полного инновационного цикла на предприятиях отечественного химпрома и научных центрах. К обсуждению были привлечены представители бизнеса, власти, науки, высшей школы и крупнейших отраслевых объединений.
\end{abstract}

Открыл совещание Президент Российского Союза химиков (РСХ) Виктор Иванов. Он объявил регламент и проблематику встречи, а также сообщил о решении Совета РСХ и Росхимпрофсоюза наградить Орденом «За заслуги перед химической индустрией" второй степени главного редактора журнала "Химия и бизнес» Анатолия Перхова, а также Орденом «За заслуги перед химической индустрией" первой степени Директора Ассоциации предприятий лакокрасочной отрасли РФ «Центрлак" Геннадия Аверьянова. По словам Президента РСX, почетной награды высококлассные специалисты и активисты отрасли были удостоены за многолетний плодотворный труд и активную работу по развитию отрасли и высокотехнологичных производств.

Указом президента РФ № 642 от 1 декабря 2016 года была утверждена Стратегия научно-технического развития России, которая определила основные приоритеты развития страны, отражающие курс на сближение науки и промышленного производства. В ходе заседания участники педантично пытались разобраться с Постановлением Минобрнауки России № 162, в котором закреплено понятие КНТП (комплексные научно-технические проекты), а также сформулированы правила их разработки, согласования, реализации и корректировки. КНТП представляют собой совокупность скоординированных по задачам, срокам и ресурсам работы, которые включают научные исследования и этапы инновационного цикла от создания технологий до получения готовой продукции. Согласно планам Министерства науки и высшего образования КНТП должны стать формой реализации частно-государственного партнерства, при котором финансирование и софинансирование проекта - зона ответственности государства, а на производстве - удачная коллаборация инженеров, технологов и ученых.

Перед собравшимися с докладом "О разработке комплексных КНТП" выступил заместитель директора Департамента научно-технических программ Минобрнауки России Аркадий Тихонов. В своем сообщении он проиллюстрировал основные этапы работы в рамках КНТП, проанализировал возможные осложнения и их причины. Докладчик также привел примеры успешных КНТП в химпроме и дал рекомендации для потенциальных участников.

Весьма полезным и интересным стало выступление генерального директора АО "Ярославские краски", члена Совета РСХ Валерия Абрамова. Он поделился личным опытом работы по КНТП, дав всем заинтересованным мощный импульс к работе и действию по проектам глубокой, но содержательной репликой: "Сложно, но можно и реально".

Заслушав и обсудив сообщение по НТП заместителя директора Департамента научно-технических программ Минобрнауки России, а также выступления 
в прениях, участники совещания рассмотрели проект Решения по вопросу “О порядке разработки и реализации комплексных научно-технических программ (КНТП) и проектов полного инновационного цикла". Отмечена важность и актуальность разработки и реализации КНТП полного инновационного цикла как одного из механизмов государственной поддержки в целях создания прорывных отечественных технологий, повышающих конкурентоспособность экономики страны.

В постановлении комиссии РСПП рекомендовано РСХ проводить необходимую информационноразъяснительную работу, а вместе с Минобрнауки РФ и Минпромторгом России организовать необходимую организационно-методологическую поддержку предприятиям химического комплекса по разработке и реализации КНТП полного инновационного цикла.

Следующий блок вопросов и дискуссий были посвящены трансформации кадровой политики на предприятиях химпрома, а также проблемам и перспективам подготовки кадров для отрасли высокотехнологичных производств. С докладом «Подготовка кадров и развитие квалификаций химического, нефтехимического и биотехнологического комплекса" выступила первый вице-президент Российского Союза химиков Мария Иванова. Она рассказала об основных тенденциях развития квалификаций в стране и ключевых векторах работы Совета по профквалификациям химического и биотехнологического комплекса. Совет активно поддерживает функционирование и развитие системы отраслевых профессиональных квалификаций. Важнейший аспект выступления состоял в анализе ключевых факторов влияния на развитие профессий в химии, а именно: инноваций, технологического развития, модернизации производств, цифровизации, повышения производительности труда, а также утверждение принципов устойчивого развития и бережливого производства. В качестве рабочих инструментов развития квалификации в условиях современной России эксперт рассматривает потенциал существующих профессиональных стандартов и профилей профессий, особенности процедуры независимой оценки квалификаций, положительные аспекты наставничества, образовательных программ и стажировок, а также конкурсов профессионального мастерства. Кроме того, Мария Иванова рассказала об основных направлениях работы СПК (Совет по профессиональным квалификациям химического и биотехнологического комплекса), в частности о запуске ЦОК (Центр оценки квалификаций). В текущем году такие Центры начали свою работу в Казани и Уфе, на 2020

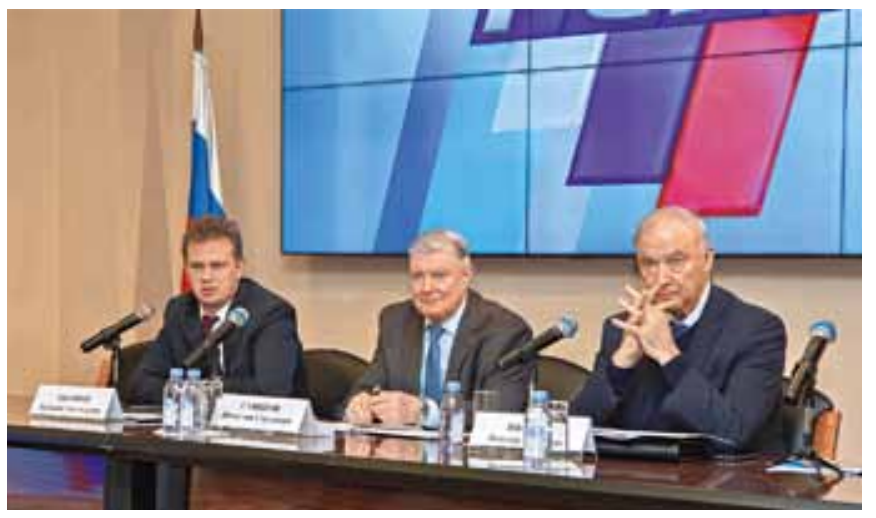

год запланирован запуск сразу трех ЦОК: в Волгограде, Перми, Ярославле.

Большой интерес у собравшихся вызвали уникальные кейсы подготовки кадров и развития химических профессий в рамках Корпоративного университета "Сибура", а также опыт развития квалификаций рынка производства минеральных удобрений, транслируемых на отрасль и собственное производство компанией "ЕвроХим". Наталья Ямщикова, директор Корпоративного университета "Сибура", не только приоткрыла "тайную кухню" настоящей кузницы кадров в нефтехимии, но и пояснила, как мобилизовать силы при подготовке специалистов для работы на уникальных, только запускаемых промышленных объектах, подобных "ЗапСибНефтехим" и АГХК.

Владимир Барановский, директор по управлению персоналом компании "ЕвроХим", пояснил нюансы в подготовке высококлассных специалистов по разработке и производству минеральных удобрений. Интересно, что это не только обучение и повышение квалификации по профильным производственным направлениям, но и создание отличной мотивационной базы. На все эти точки роста кадров компания не жалеет ни сил, ни времени. Ежегодные затраты на кадры у "ЕвроХим" не менее 100 млн руб., и это не предел.

Есть свои особенности в подготовке специалистов и в высшей школе.

Проректор по учебной работе РХТУ им. Д. И. Менделеева Сергей Филатов рассказал об универсальной модульной системе, которая дополняется специальными опциями в зависимости от выбранной специальности и учитывает все современные мировые и отечественные "вызовы и траектории" химикотехнологического образования. Перспективы развития химического образования в России, в том числе в рамках Болонской конвенции, эксперт видит главным образом в сетевом образовании и глобальной образовательной мобильности. Из недостатков форматной 
работы с предприятиями химпрома Сергей Филатов называет несовершенство нормативно-правового регулирования отношений между вузом и работодателем.

Заместитель декана факультета фундаментальной физико-химической инженерии МГУ им. М. В. Ломоносова Людмила Григорьева в своем выступлении о базисах фундаментального инженерного образования в России отметила предпосылки развития и углубления инженерного образования в нашей стране. Необходимость системных и взвешенных подходов и действий в этом направлении усвоена и декларируется на самом высоком уровне: уже два года подряд в ежегодном послании Федеральному собранию РФ Президент подчеркивает важность развития инженерного образования и модернизации общего и высшего образования в целом. Откликаясь на эти требования, факультет фундаментальной физико-химической инженерии МГУ им. М.В. Ломоносова непрерывно совершенствует подход к учебному процессу, обеспечивая уникальное практико-ориентированное междисциплинарное образование. Выпускники факультета востребованы и успешно работают в группе компаний «Инэрджи", в "Роснефти", Росатоме, "Сибуре», "Алмаз-Антей", на предприятиях по производству научного и технологического оборудования. Людмила Григорьева с сожалением отметила отсутствие инженерных общепрофессиональных компетенций в базовой части актуальных стандартов, что в настоящий момент осложняет для вузов подготовку высококлассных специалистов согласно ФГОС. Предложение высшей школы - конкретное и, к слову, уже оформленное документально: внедрить стандарт по фундаментальной инженерии, который свяжет все этапы образования с реальным сектором экономики через научную и инженерно-технологическую деятельность на основе интеграции различных областей знаний, инноваций, конструктивности всех участников образовательного

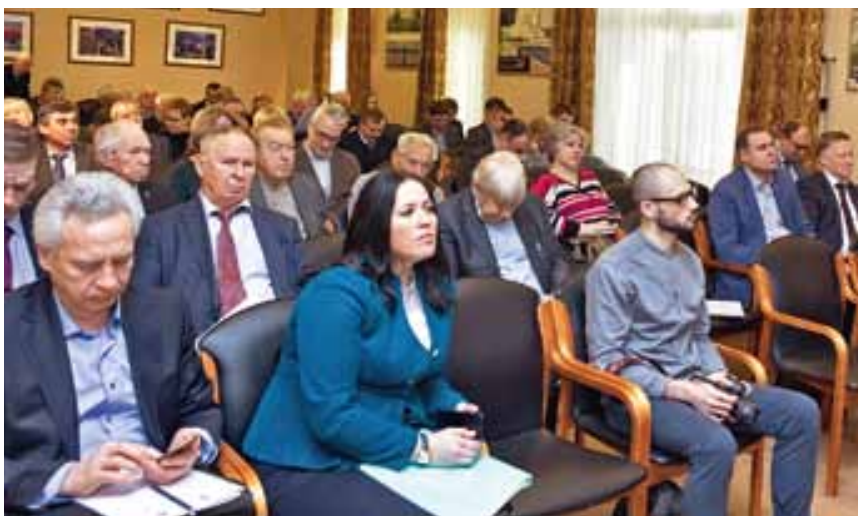

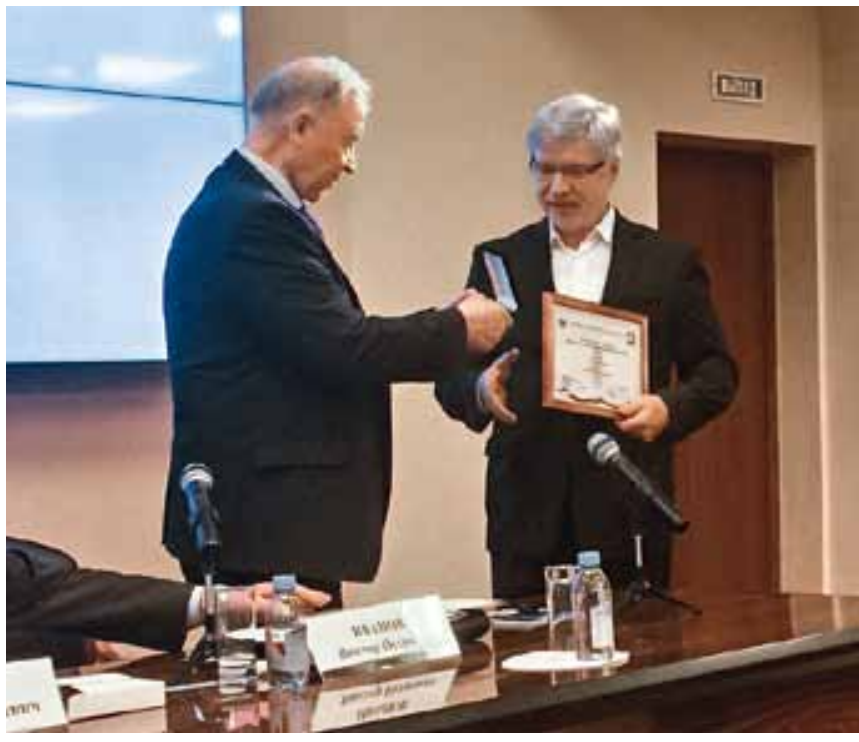

и производственных процессов. Инициатива уникального факультета в рамках внедрения проектов новых ФГОС ВО уровня бакалавриата и магистратуры по направлению подготовки «Фундаментальной инженерии" была поддержана большинством участников совместного заседания Комиссии РСПП по химической промышленности и Совета Российского Союза химиков.

Другой не менее интересной инициативой по популяризации рабочих профессий в России стало предложение организовать и провести Всероссийский конкурс «Лучший лаборант-химик". Дмитрий Черняев, первый заместитель руководителя ГК "Термика", отметил острую нехватку мероприятий такого формата, способных создать благоприятный образ профессии в химии и привлечь в нее молодые и перспективные кадры. В итоге, по второму вопросу комиссии участники утвердили отдельный проект решения, поддержав предложение группы компаний “Термика" по проведению Всероссийского конкурса "Лаборант-химик".

В заключение заседание приняло ряд решений.

1. Предложить предприятиям химического, нефтехимического и биотехнологического комплекса продолжить разработку профессиональных стандартов и актуальных отраслевых рамок квалификаций по видам деятельности, а также внести предложения в “Справочник востребованных на рынке труда, новых и перспективных профессий".

2. Профессиональному сообществу предложить направить кандидатуры экспертов в единую базу СПК химического и биотехнологического комплекса по направлениям: разработка профессиональных стандартов, квалификаций 
и оценочных средств; проведение процедуры независимой оценки квалификаций.

3. Рекомендовать Совету по профессиональным квалификациям расширить сеть Центров оценки квалификаций в регионах присутствия химических предприятий для более эффективного и оперативного прохождения независимой оценки в соответствии с действием положений Федерального закона "О независимой оценке квалификации" от 3 июля 2016 года № 238-Ф3.

4. Совету Российского Союза химиков и СПК рассмотреть возможность организации сотрудничества с Союзом "Агентство развития профессиональных сообществ и рабочих кадров (Ворлдскилс Россия)», в том числе по вопросу присвоения квалификаций по результатам демонстрационного экзамена по стандартам "Ворлдскилс", а также проведении профессиональной переподготовки лиц предпенсионного возраста в рамках государственных субсидий.

5. Предложить компаниям и предприятиям химического, нефтехимического и биотехнологического комплекса принять активное участие в рассмотрении проекта "Стратегия развития национальной системы квалификаций на период до 2030 г.".

6. Предложить РХТУ им. Д. И. Менделеева разработать перечень совместных программ для реализации в химико-технологических вузах по наиболее востребованным направлениям подготовки специалистов.

7. Рекомендовать к дальнейшему утверждению проекты федеральных государственных образовательных стандартов высшего образования "Фундаментальная инженерия", разработанные с учетом задач инновационной деятельности ведущих химических компаний и Стратегии научно-технологического развития РФ.

\section{МЕЖДУНАРОДНЫЙ МОЛОДЕЖНЫЙ НАУЧНЫЙ ФОРУМ "ЛОМОНОСОВ-2020"}

С 13 по 17 апреля 2020 года в Московском государственном университете имени М. В. Ломоносова состоится традиционная Международная научная конференция студентов, аспирантов и молодых үченых "Ломоносов". Она проводится в рамках Международного молодежного научного форума "Ломоносов", председатель Оргкомитета - ректор Московского университета академик Виктор Антонович Садовничий.

Организаторы: Московский государственный университет имени М. В. Ломоносова, Российский союз студенческих организаций, Студенческий союз МГУ имени М. В. Ломоносова.

Основная цель конференции "Ломоносов" - развитие творческой активности студентов, аспирантов и молодых ученых, привлечение их к решению актуальных задач современной науки, сохранение и развитие единого международного научнообразовательного пространства, установление контактов между будущими коллегами.

В 2020 году работа Конференции будет проходить по 39 секциям, отражающим все основные направления современной фундаментальной и прикладной науки.
Секция "химия» разделена на подсекции:

- "Аналитическая химия";

- "Высокомолекулярные соединения»;

- "Дисперсные системы и поверхностные явления»:

- "История химии»;

- «Катализ»;

- «Неорганическая химия I (студенты)»;

- «Неорганическая химия II (аспиранты и молодые ученые)";

- "Органическая химия»;

- «Радиохимия и радиоэкология»;

- «Физическая химия I: молекулярное моделирование, спектроскопия, лазерная химия»;

- «Физическая химия II: химическая термодинамика и химическая кинетика»;

- «Физическая химия III: процессы с участием ионов и радикалов в конденсированных средах и на межфазных границах (электрохимия, химия высоких энергий, спиновая химия)»;

- "Химическая технология и новые материалы»;

- «Химия живых систем, нанобиоматериалы и нанобиотехнологии".
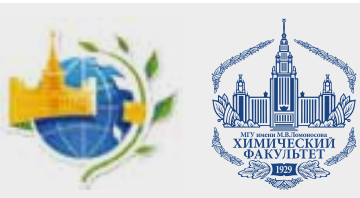

Для участия в конференции приглашаются студенты (специалисты, бакалавры или магистры), аспиранты, соискатели и молодые ученые любой страны мира в возрасте до 35 лет - учащиеся или сотрудники российских и зарубежных вузов, аспиранты и сотрудники научных учреждений.

Проведение Конференции "Ломоносов" поддержано грантом Президента Российской Федерации на развитие гражданского общества, предоставленным Фондом президентских грантов на проект «Международный молодежный научный форум "Ломоносов".

В рамках Международного молодежного научного форума "Ломоносов-2020" пройдут следующие мероприятия:

- Международный конкурс инновационных проектов и стартапов «Потенциал будущего» (14-17 апреля).

- Конференция «Современные образовательные траектории» (14-16 апреля).

- Международный конгресс молодых ученых (14-17 апреля).

https://lomonosov2020.chem.msu.ru 